\title{
Accuracy of Imaging Investigations in Pancreatic Cancer Diagnosis
}

\author{
LORENA SAS ${ }^{1}$, OANA TAISESCU ${ }^{1}$, STEFAN-ALEXANDRU ARTENE ${ }^{2}$, ANICA DRICU2*, THEODOR SAS ${ }^{3}$, DUMITRA GINDROVEL ${ }^{4}$, \\ CITTO IULIAN TAISESCU 5 \\ ${ }^{1}$ University of Medicine and Pharmacy of Craiova, Department of Anatomy, 2 Petru Rares Str., 200349, Craiova, Romania \\ 2 University of Medicine and Pharmacy of Craiova, Department of Biochemistry, 2 Petru Rares Str., 200349, Craiova, Romania \\ ${ }_{13}$ University of Medicine and Pharmacy of Craiova, Department of Radiology, 2 Petru Rares Str., 200349, Craiova, Romania \\ ${ }^{4}$ University of Medicine and Pharmacy of Craiova, Department of Pediatrics, 2 Petru Rares Str., 200349, Craiova, Romania \\ ${ }^{5}$ University of Medicine and Pharmacy of Craiova, Department of Physiology, 2 Petru Rares Str., 200349, Craiova, Romania
}

\begin{abstract}
Pancreatic adenocarcinomas are considered one of the most complicated cancers in terms of treatment options and patient management. Regarding the diagnosis of pancreatic cancers, imaging techniques still play the central role with multiple options such as Computer Tomography (CT), Ultrasound (US), orEndoscopic Ultrasound (EUS) being available. The study was conducted at the Emergency County Hospital of Craiova, at the Radiology and Medical Imaging Department, the Imaging Compartment of the Research Center of Gastroenterology and Hepatology Research Center, on 170 patients suffering from pancreatic cancer, mostly adenocarcinomas. The neoplastic lesions were described using either US, CT or EUS techniques. The location of the tumor was assessed suing US and CT examination for all 170 patients in the study. There was a statistically significant correlation ( $<0.0001)$ between US and CT examination in terms of accuracy, with both techniques proving to be highly reliable. For measuring tumor size, 31 patients were evaluated using CT and EUS techniques. EUS proved to be more accurate in comparison to CT examination, with $9(27 \%)$ of the total 31 patients having their tumor size underestimated by CT examination. There are no notable differences between the US evaluation of the tumor location and the actual location identified at the CT scan. As for tumor size, EUS showed greater reliability in evaluating tumor size in comparison to CT examination.
\end{abstract}

Keywords: Ultrasonography; Computer Tomography; Endoscopic Ultrasound; Pancreatic Adenocarcinoma

Imaging explorations play an essential role in the diagnosis, stadialization and therapeutic approach of pancreatic cancer.

Computer tomography (CT) uses X-rays, spiral CT being the standard examination for the majority of clinical indications [1]. The continuous scanning along with simultaneous data aquisition and the subsequent reduced examination period represent the advantages of this technique.

Ultrasound examination (US) possesses a very high accuracy rating in children and slender patients. Standard US requires adequate patient preparation, who often present abdominal distention, which leads to a difficult examination of the pancreas [2]. The correct assessment is highly influenced by the examiner's experience who is confronted with the direct examination of a small gland which has altered visceral and vascular relations when a neoplastic procces is present. A couple of situations in which the visualization of the pancreas can be hindered can be mentioned: overweight patients, entero-enteral anastomosis which are tractioned towards the front, abdominal scar tissues [3].

Because of abdominal distention and their isoechoic aspect small cephalic tumors of can remain hidden during the US examination. This is the main reason why echoendoscopy is recommended as the prefered exploratory imaging method [4]. Tumors with a diameter greater than $3 \mathrm{~cm}$ may determine duodenal compression and invasion. Hypoechoic and round lymph nodes can often be visualized around hepatoduodenal ligament, which are indicative for a malign tumor [5].

Endoscopic ultrasound (EUS) consists of a high frequency $(5-12 \mathrm{MHz})$ transductor placed at the tip of an endoscope which allows the transmural view of the $\mathrm{Gl}$ tract and the adjacent structures [6]. EUS offers highquality images in comparison to the transabdominal US, as it avoids interposed structures such as air and adipose tissue.

EUS is a highly sensitive method in tumor staging and surgical resectability of pancreatic neoplasms. It is used to localize endocrine tumors and to assess the vascular supply of pancreatic duct and tumors smaller than $3 \mathrm{~cm}$. $\mathrm{CT}$ and MRI are used alongside endoscopy to accurately evaluate the vascular invasion [7].

Also, EUS can precisely appreciate the tumor size and offers data on the level of local extension. However, it cannot detect hepatic and lymph node metastasis.

\section{Aim of the paper}

This paper aims to evaluate patients' status based on diagnostic algorythms by testing and correlating the imaging methods (CT, US and contrast-enhanced US) with the diagnosis, in a prospective fashion.

\section{Experimental part}

Materials and methods

The study was conducted at the Emergency County Hospital of Craiova, at the Radiology and Medical Imaging Department, the Imaging Compartment of the Research Center of Gastroenterology and Hepatology Research Center.

The study consisted of 170 patients suffering predominantly from pancreatic adenocarcinoma.

The CT examination was performed using SIEMENS SOMATOM with 20 spires. CT exploration was performed in a sequential fashion, unenhanced or with oral and intravenous administration of non-iodine based contrast agents. The continuous scanning resulted in a reduced 
exposure time and a simultaneous data acquisition during a single period of apnea, which excluded any respiratory artifacts. Gastrografin was administered orally in 2 phases: $200 \mathrm{~mL} 20$ min prior to the CT examination and $400 \mathrm{~mL}$ immediately before the procedure. The purpose of the contrast agent is to distend and enhance opacifiation of the duodenum.

Transabdominal US was accomplished using the ALOKA SSD 5000 and HITACHI 8500 EUB US equipment. The examination was performed á jeun in a dorsal and/or left lateral decubitus positioning, using a convex transductor with a frequency of 3.5-5 Mhz or 2.5 Mhz for overweight patients. Axial, oblique and sagittal sections were obtained.

Echo-endoscopy was performed using a Olimpus UCT linear echo-endoscope with a frequency range of 5 to 10 Mhz, coupled with an ALOKA PROSOUND 5000 US equipment and the HITACHI EUB 8500 coupled with the Pentax linear echo-endoscope (EG 383 OUT). The examination was performed in a conscious sedation state

Table 1

PATIENT DISTRIBUTION ACCORDING TO THE PANCREATIC LOCATION

\begin{tabular}{|c|c|c|c|}
\hline Group & Pancreatic level & $\begin{array}{c}\text { US } \\
\text { General arm }\end{array}$ & $\begin{array}{c}\text { CT } \\
\text { General arm }\end{array}$ \\
\hline 1 $^{\text {st }}$ AREA & cephalic & 113 & 108 \\
\hline $2^{\text {nd }}$ AREA & body & 35 & 47 \\
\hline $3^{\text {rd }}$ AREA & caudal & 22 & 15 \\
\hline \multicolumn{2}{|c|}{ Total } & 170 & 170 \\
\hline
\end{tabular}



Fig. 2. Axial CT section -Pancreatic head adenocarcinoma with intravenous midazolam (Dormicum) and in a small percentage of patients with intravenous propofol.

\section{Results and discussions}

A. Correlations between US and CT studies

The first statistical data correlations regarding the location of the pancreatic tumors and the chosen imaging techniques (US and CT) included 170 patients, who were separately examined using both methods.

Segmentation analysis yielded location discrepancies between US and CT.

For ten of them, US examination indicated the location in a close proximity segment as seen on the CT scan. Thus, five tumors located in the cephalic region were assessed as belonging to the adjacent area according to the CT scan. Likewise, seven tumors located in the body, at the limit with the caudal region, were considered to belong to the latter.
Fig.1.Transabdominal US - enlarged gallbladder, cephalic mass with common bile duct compression
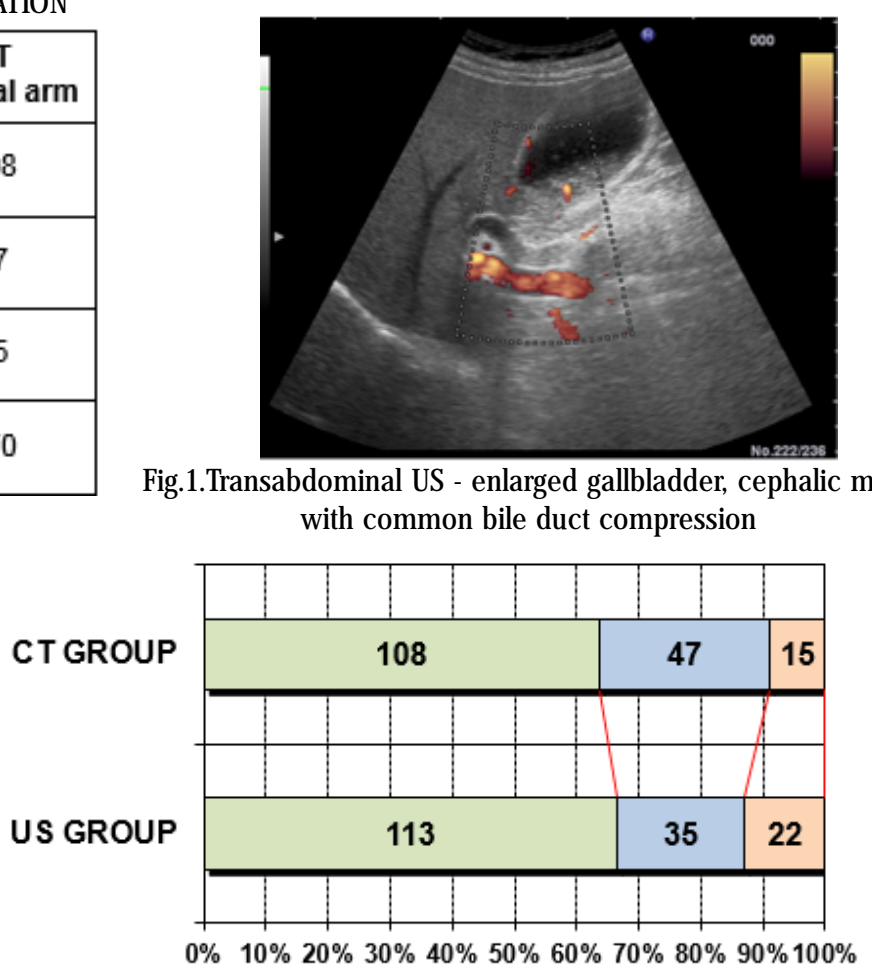

$\square$ AREA I / Cephalic $\square$ AREA II / Corporeal $\square$ AREA III / Caudal

Fig.3. Percentage of different anatomical locations depending on the investigation method

Table 2

RESULTS OF CHI-SQUARED TEST BETWEEN THE ANATOMICAL LOCATION AND THE INVESTIGATION METHODS

\begin{tabular}{|c|c|c|c|c|c|}
\hline & \multicolumn{3}{|c|}{ CT group } & \\
\hline & & $1^{\text {st }}$ AREA & $2^{\text {nd }}$ AREA & $3^{\text {rd }}$ AREA & \\
\hline \multirow{3}{*}{ 음 } & $1^{\text {ts }}$ AREA & 108 & 5 & 0 & \\
\hline & $2^{\text {nd }}$ AREA & 0 & 47 & 5 & \\
\hline & $3^{\text {rd }}$ AREA & 0 & 7 & 15 & \\
\hline & \multirow{2}{*}{\multicolumn{2}{|c|}{$X^{2} \operatorname{tes} t$}} & $\overline{\mathrm{DF}}$ & Value & p \\
\hline & & & 4 & 177.125 & $<0.0001$ \\
\hline
\end{tabular}


Statistical evaluation of data was performed usind the $\chi 2$-test. In this situation, the $p$ value for each result obtained through the $\chi 2$-test supported the correlation between tumor location and imaging methods.

Thus, the corresponding diagram of the contingency table clearly illustrates the correlation between the head, body, tail US distribution and $1^{\text {st }}$ area, $2^{\text {nd }}$ area, $3^{\text {rd }}$ area CT distribution. There are no notable differences between the US location of the tumor and the real location identified by the CT scan.

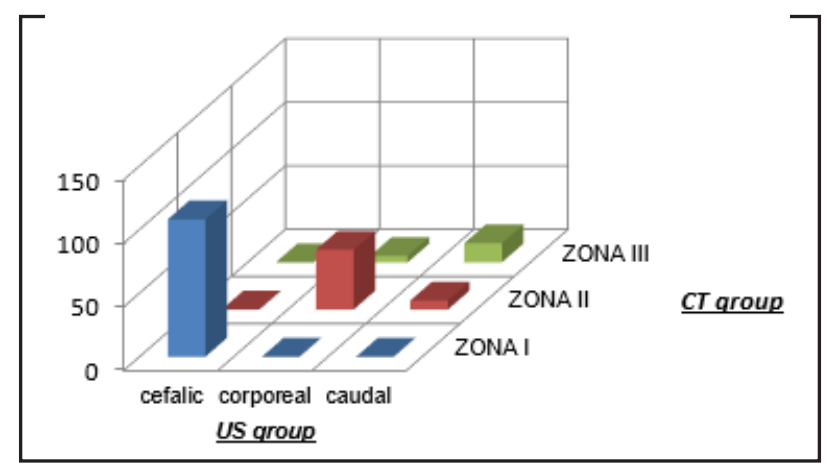

Fig.4. Contingency diagram of Chi-squared test

The relative evaluation error of all of the cases is due to the big size of the tumoral process or the shape which gives the illusion of a certain location with extension to the neighbouring area. Hence, we considered the tumor location determined with US as having a high grade of relative correlation with the location found using CT examination.

\section{B.Correlations between echo-endoscopic and CT studies}

32 patients were selected for the statistical analysis, of whom, 30 presented adenocarcinoma and 2 insulinoma.

The vascularisation index (VI) was calculated as the percentage of pixels with Doppler power signal from the total number of pixels in the region of interest (ROI); ROI was selected within the pancreatic mass. Thus, IV is the average of each venous phase (sequences from a 10 second film) after the contrast substance reached the portal system, the splenic or superior mesenteric vein (usually 30 to 35 seconds post-contrast administration). A $20 \%$ cut-off value of the VI (determined with the help of EUS with power Doppler contrast) was used to differentiate hypervascularity from hypovascularity.
The pulsatility and resistance indices obtained with spectral Doppler analysis of each tumoral blood vessels were used to differentiate benign focal masses from malignant ones.



Fig. 5.Pancreatic adenocarcinoma
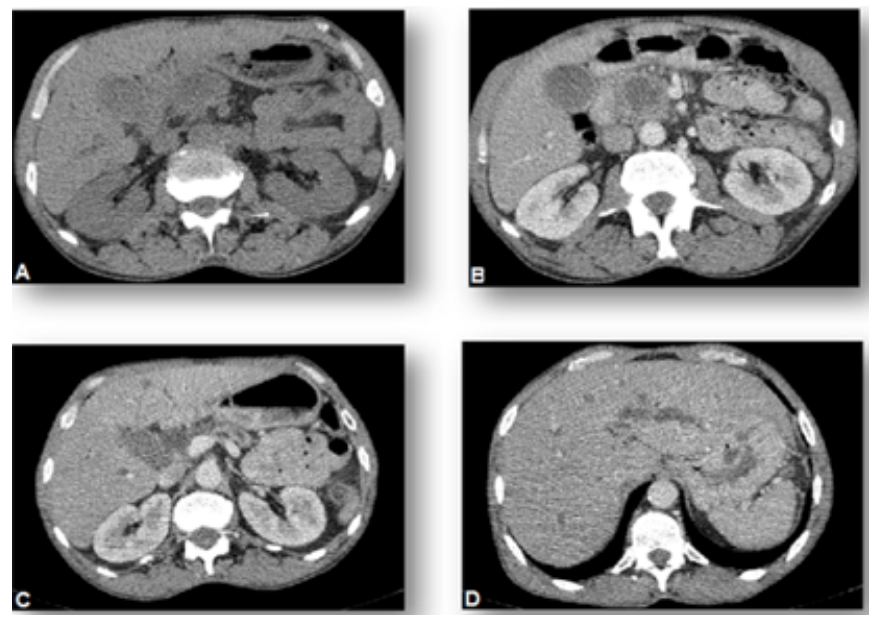

Fig.6.Unenhanced CT scan (A), and with i.v. contrast medium (B), axial plan, shows a $3.75 / 3.44 \mathrm{~cm}$ tumoral mass, localised at the cephalic level with areas of central necrosis - adenocarcinoma characteristics

Global assessment of tumor size (determined by EUS and CT) contributed to the classification in three class categories $(\mathrm{I}=<2 \mathrm{~cm}, \|=2-4 \mathrm{~cm}, \mathrm{III}=>4 \mathrm{~cm})$.

CT scan determined more cases of class II tumors in comparison to EUS, where the predominant cases were class I.

\begin{tabular}{|c|c|c|c|}
\hline & $\begin{array}{c}\text { Insulinoma } \\
\mathrm{n}=2\end{array}$ & $\begin{array}{c}\text { Pancreatic adenocarcinoma } \\
\mathrm{n}=30\end{array}$ & Statistical significance \\
\hline Age (years) & $48.5 \pm 1.90$ & $62.85 \pm 1.26$ & $<0.001$ \\
\hline Gender (female/male) & $2 / 0$ & $10 / 20$ & 0.0040 \\
\hline $\begin{array}{c}\text { Tumor localization } \\
\text { (head/bodyitail) }\end{array}$ & $2 / 0 / 0$ & $23 / 4 / 3$ & 0.0338 \\
\hline $\begin{array}{c}\text { Tumor size } \\
\text { Focal(cm) }\end{array}$ & $2 \pm 0.165$ & $4.44 \pm 1.22$ & $<0.0012$ \\
\hline $\begin{array}{c}\text { Cytologic analysis } \\
\text { (positive/negative) }\end{array}$ & $0 / 2(0 \%)$ & $4 / 26(83.7 \%)$ & 0.0130 \\
\hline $\begin{array}{c}\text { Vascularisation index } \\
\text { (pre-contrast) }\end{array}$ & $6.40 \pm 1.174$ & $2.96 \pm 0.590$ & $<0.001$ \\
\hline $\begin{array}{c}\text { Vascularisation index } \\
\text { (post-contrast) }\end{array}$ & $26.10 \pm 2.870$ & $10.0 \pm 1.499$ & 0.0044 \\
\hline $\begin{array}{c}\text { Pulsatility index } \\
\text { Resistance index }\end{array}$ & $1.40 \pm 0.099$ \\
$0.71 \pm .023$ & $1.84 \pm 0.120$ & 0.0290 \\
\hline
\end{tabular}

Table 3

PATIENTS' DATA 
Table 4

TUMOR SIZE-CT/EUS

\begin{tabular}{|l|c|c|c|}
\hline Class & Endoscopic size & EUS group & CT group \\
\hline$I$ & $<2 \mathrm{~cm}$ & 10 & 6 \\
\hline $\mathrm{II}$ & $2-4 \mathrm{~cm}$ & 14 & 15 \\
\hline $\mathrm{III}$ & $>4 \mathrm{~cm}$ & 8 & 11 \\
\hline
\end{tabular}

Table 5

RESULTS OF THE CHI-SQUARE CORRELATION TEST BETWEEN THE TUMOR DIMENSIONS DESCRIBED BY THE TWO INVESTIGATION

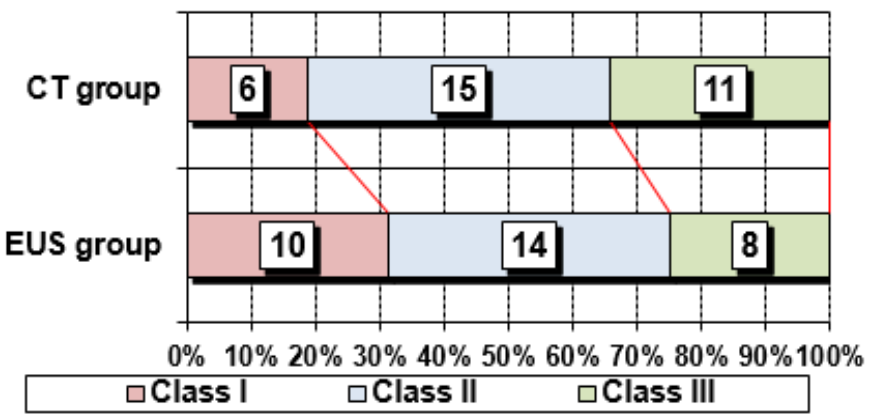

Fig. 7. Tumor size -CT/EUS METHODS

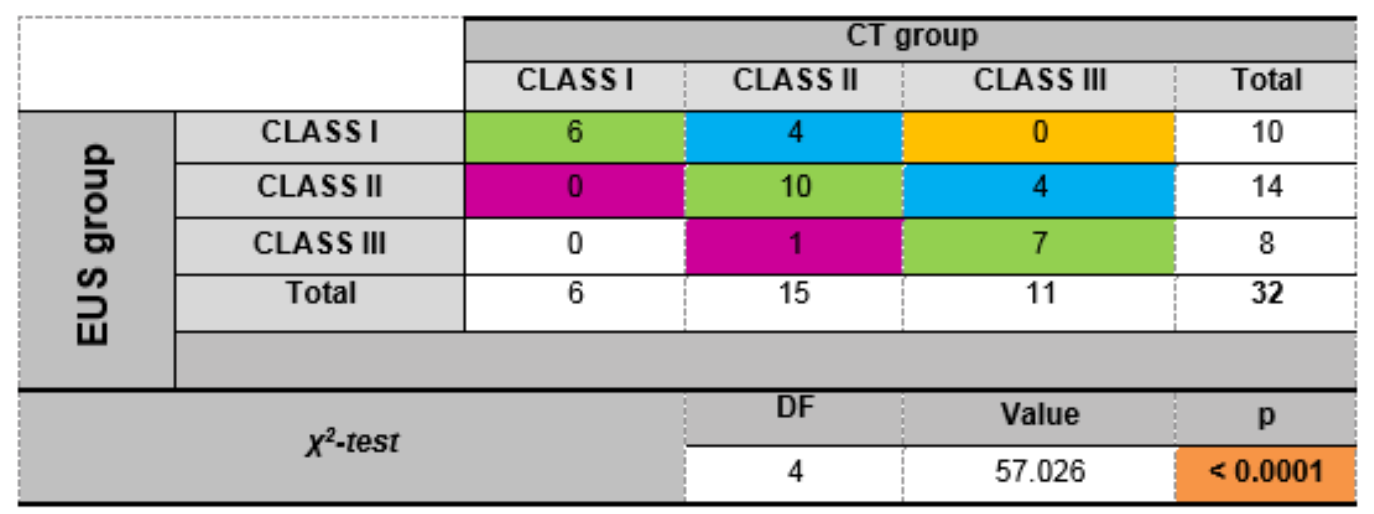

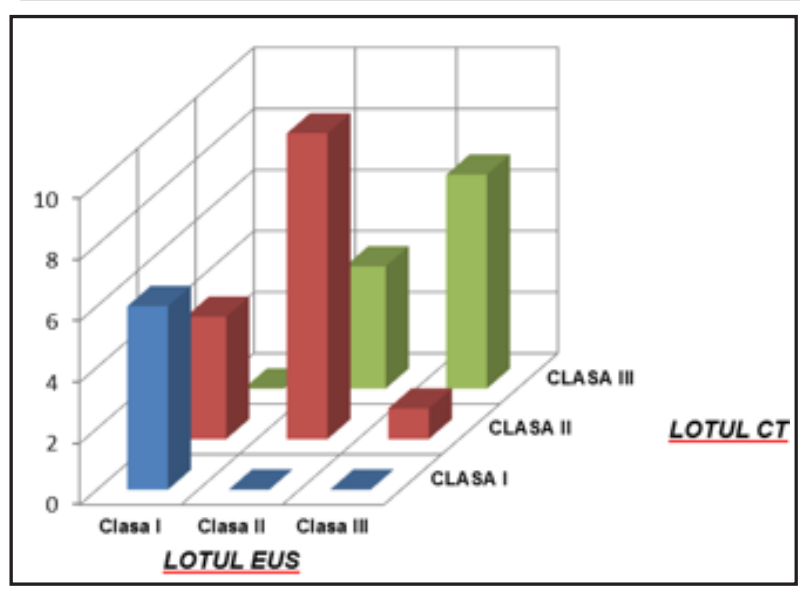

Fig. 8. Contingency chart of the chi-square correlation test

$\chi 2$-test was used to assess the correlation between the two imaging methods to measure the size of the carcinomas.

The correlation between the investigation methods and the tumor measurements proved to have high significance, fact supported by the $p$-values determined for each value of the chi-square test.

The comparative analysis of the tumor measurements in 23 patients ( $73 \%$ of all cases) was considered concordant, while, for the other 9 patients, differences between measurements were observed. For 8 out of 9 patients, the discrepancy consisted in the underestimation of measurements performed with the CT scan in comparison to EUS, the latter being of greater reliability in detecting tumor size.

One case was recorded as over-evaluation discrepancy in tumor size, the tumor being an insulinoma which could not be detected by CT scan, only by echo-endoscopy.

Overall, CT examination underestimated tumor size in a significant percentage of cases compared to the EUS, the underestimation resulting from the assessment of the surface dimensions and not the total size, which proved to be more extended.
Table 6

STATISTICAL PARAMETERS OF TUMOR SIZE (EUS, CT)

\begin{tabular}{|c|c|c|c|}
\hline $\begin{array}{l}\text { Statistical } \\
\text { Parameter }\end{array}$ & EUS group & \multicolumn{2}{|c|}{ CT group } \\
\hline MAX-SIZE & $5 \mathrm{~cm}$ & \multicolumn{2}{|c|}{$5.03 \mathrm{~cm}$} \\
\hline$A V G$ SIZE+STDEV & $5.65 \mathrm{~cm}$ & \multicolumn{2}{|c|}{$6.5 \mathrm{~cm}$} \\
\hline MEDIAN & $3.2 \mathrm{~cm}$ & \multicolumn{2}{|c|}{$3.7 \mathrm{~cm}$} \\
\hline AVG-SIZE & $3.54 \mathrm{~cm}$ & \multicolumn{2}{|c|}{$4.04 \mathrm{~cm}$} \\
\hline AVG-SIZE-STDEV & $1.53 \mathrm{~cm}$ & \multicolumn{2}{|c|}{$1.58 \mathrm{~cm}$} \\
\hline -MIN-SIZE & $1.5 \mathrm{~cm}$ & \multicolumn{2}{|c|}{$1.8 \mathrm{~cm}$} \\
\hline STDEV & 2.01 & \multicolumn{2}{|c|}{2.46} \\
\hline \multirow{2}{*}{$t=$ test } & $\overline{D F}$ & $\overline{\text { Value }}$ & $\bar{p}$ \\
\hline & 170 & -0.826 & 0.409 \\
\hline
\end{tabular}

This conclusion is supported by the study of statistical parameters regarding measurements performed by EUS exploration and CT evaluation. Statistical analysis using ttest did not validate the difference in tumor size in the two arms in terms of mean value or size distribution.

Thus, tumor size variation range was more extensive in the CT lot than in the EUS lot. However, the range in which most of the values converged, defined by STDEV around the mean value was more pronounced in both arms and shifted to the upper limit of the value variation range due to average sizes that were, in both cases, higher than the mean value of the tumor diameter. Tumors analyzed with CT had a mean tumor diameter greater than those measured by EUS.

Pancreatic cancer is listed as being the forth on the list of cancer-related deaths. This very poor prognosis is related to the high agresiveness of the tumor, lack of therapeutic options with a resistance to most major treatment options and late diagnosis $[8,9,10]$, usually during locally advanced or metastastic stages. In the past decades the research community has focused on elaborating a genetic profile for pancreatic cancers [11-13], identifying several key 
factors such as tyrosine kinase receptors such as the Epithelial Growth Factor Receptor (EGFR) or it's ligand EGF $[14,15]$. Angiogenesis is another major factor implicated in cancer development, playing a central role in other cancers such gliomas [16, 17]. Unfortunately, it's importance is still debatable in pancreatic cancers $[18,19]$.

Spiral CT is currently the preferred imaging method for pre-operative detection, assessment, and staging of pancreatic cancer [20]. Moreover, the method reveals possible parenchymal or bone metastases included in the acquisition plan, peripancreatic adenopathies and peritoneal carcinomatosis [21, 22]. The detection of pancreatic tumors is possible using 1-3 mm sections uand high resolution contrast agents, CT accuracy for detecting pancreatic cancer being $97 \%$. CT determines the aggressiveness of pancreatic cancer by assessing invasion of the visceral, serous and vascular structures [23- 25]. Evaluation of the peripancreatic vascular invasion of superior mesenteric vein and artery, portal vein, hepatic artery is appreciated from the compression and occlusion signs of the vessels with the formation of collateral vascular vessels (a clear sign of tumor unresecability) [26, 27].

The drawbacks of CT scan include the use of X-rays and conditions prohibiting the use of iodine-based contrast agents,the most important being: renal failure, severe heart failure, history of allergic reactions [28-30].

Usually, imaging exploration of the pancreas begins with an US and it is preferrable to performthe technique in the morning because of the low level of digestive secretions [4]. The approach is epigastric with transverse and oblique sections. For a better examination, the patient is required to execute a deep inspiration and hold it for as long as possible (Valsalva maneuvre), so that the left hepatic lobe descends anteriorly and offers a good exploration window [3].

The most frequent location of pancreatic adenocarcinoma is at the cephalic level, accompanied by signs of invasion or compression of the common bile duct with subsequent dilation of intrahepatic bile duct and gallbladder which gives the appearance of hydrops and bile sediment $[2,31]$. There is also retrograde dilation of W irsung's duct, which can reach $20 \mathrm{~mm}$ or more. During an US evaluation, the differential diagnosis is made with chronic cephalic pancreatitis, pancreatic cysts, retroperitoneal adenopathy, common bile duct tumors and vaterian ampulloma.

Adenocarcinoma located at the pancreatic body is rarely encountered and has a rapid extracapsular development; in case of a large neoplastic mass, central necrosis can be observed [32-34]. The posterior extension can result in the invasion of the aorta, superior mesenteric artery and vein, celiac trunk and splenic vein, while the anterior extension can dislocate the stomach. The invasion of the superior mesenteric artery can be evidenced by Doppler mode [ 6 , 35]. The differential diagnosis is made either pancreatic pseudocysts or pseudotumoral chronic pancreatitis.

Caudal adenocarcinoma (10-15\% of the cases) is usually discovered at an advanced stage with the invasion of the posterior wall of the stomach, left kidney and adrenal gland, splenic artery and vein, celiac trunk with signs of splenic hilum thrombosis [32, 38, 39].

Current literature claims that EUS plays an important role in identifying lesions located in the body and tail of the pancreas, having a $77 \%$ sensitivity $[36,40,41]$. It has a greater sensitivity in insulinoma detection allowing fineneedle aspiration under US guidance. Most often, insulinoma appears as a homogeneous, hypoechoic, welldefined mass, sometimes presenting a capsule with irregular surface [37, 42].

\section{Conclusions}

The results of the study clearly correlate the US distribution in head, body and tail with the CT distribution in the $1^{\text {st }}$ area, $2^{\text {nd }}$ area and $3^{\text {rd }}$ area. Also, there are no notable differences between the US evaluation of the tumor location and the actual location identified at the CT scan.

The relative error of localization was due to large tumor dimensions and shapes, this being the main reason why we considered that US had a high degree of relative concordance, consistent with the location established by CT.

Taking into consideration the comparative study between CT and contrast US, a higher incidence of tumors ranging from two to four centimeters were observed in CT analysis compared to the EUS lot, where there were more lesions under two centimeters.

The comparative analysis of tumor size was assessed as concordant by the two evaluation modalities in 23 patients, representing $73 \%$ of all studied cases. The discrepancy consisted in underestimation of the measurements calculated with the CT scan versus the ones calculated with EUS, the latter showing greater reliability in tumor size.

\section{References}

1.CASSINOTTO, C., MOURIES, A., LAFOURCADE, J.P. et al. Locally advanced pancreatic adenocarcinoma: reassessment of response with CT after neoadjuvant chemotherapy and radiation therapy. Radiology 2014; 273: 108-116.

2.BUETOW, P.C., BUCK, J.L., PANTOGRAG-BROWN, L. et al. Solid and papillary epithelial neoplasm of the pancreas: imaging-pathologic correlation on 56 cases. Radiology 1996; 199: 707-711.

3.TAMM, E.P., BALACHANDRAN, A., BHOSALE, P.R. et al. Imaging of pancreatic adenocarcinoma: update on staging/resectability. Radiol Clin North Am 2012; 50: 407-428.

4.RAMAN, S.P., SALARIA, S.N., HRUBAN, R.H., FISHMAN, E.K. Groove pancreatitis: spectrum of imaging findings and radiology-pathology correlation. AJ R Am J Roentgenol 2013; 201: W29-39.

5.VILMANN, P., JACOBSEN, G.K., HENRIKSEN F.W., HANCKE, S. Endoscopic ultrasonography with guided fine needle aspiration biopsy in pancreatic disease. Gastrointest Endosc 1992; 38: 172-173.

6.ROCKALL, A.G., REZNEK, R.H. Imaging of neuroendocrine tumours (CT/MR/US). Best Pract Res Clin Endocrinol Metab 2007; 21: 43-68.

7.SHETTY, D., BhHATNAGAR, G., SIDHU, H.S. et al. The increasing role of endoscopic ultrasound (EUS) in the management of pancreatic and biliary disease. Clin Radiol 2013; 68: 323-335.

8.TIERANU, E.N., DONOIU, I., ISTRATOAIE, O. et al. Rare case of singhe coronarz arterz in a patient with liver cirrhosis. Romanian J ournal Of Morphology And Embryology. 2017; 58(4): 1505-1508

9.DEMETRIAN, C., DEMETRIAN, A., MEUNIER, J. et al. Romanian J ournal Of Morphology And Embryology. 2013; 54(4): 1005-1017

10.STREBA, C.T., GILTAN, A.M., GHEONEA, I.A. et al. Romanian J ournal Of Morphology And Embryology. 2016; 57(4): 1221-1227

11.MIREA, O., CORICl, O.M., BERCEANU, M., DONOIU, I., MILITARU, C., ISTRATOAIE, O. Acta Cardiol. 2018 J un 18: 1-10

12.MIREA, O., BERCEANU, M., DONOIU, I., MILITARU, C., SAFTOIU, A., ISTRATOAIE, O. Echocardiography. 2019 J an; 36(1): 102-109

13. OLARU, M., MALAESCU, D., DEMETRIAN, A. et al. Romanian Journal Of Morphology And Embryology. 2013; 54(4): 1067-1074

14.QING, L., QING, W.. Development of epidermal growth factor receptor targeted therapy in pancreatic cancer. Minerva Chir 2018; 73: 488-496.

15.OLIVEIRA-CUNHA, M., NEW MAN, W.G., SIRIWARDENA, A.K. Epidermal growth factor receptor in pancreatic cancer. Cancers (Basel) 2011; 3: 1513-1526.

16.SERBAN, F., ARTENE, S.A., GEORGESCU, A.M. et al. Epidermal growth factor, latrophilin, and seven transmembrane domaincontaining protein 1 marker, a novel angiogenesis marker. Onco Targets Ther 2015; 8: 3767-3774. 
17.CARAPANCEA, M., ALEXANDRU, O., FETEA, A.S. et al. Grow th factor receptors signaling in glioblastoma cells: therapeutic implications. J Neurooncol 2009; 92: 137-147.

18.LI, S., XU, H.X., WU, C.T. et al. Angiogenesis in pancreatic cancer: current research status and clinical implications. Angiogenesis 2018. 19.ZHANG, Z., JI, S., ZHANG, B. et al. Role of angiogenesis in pancreatic cancer biology and therapy. Biomed Pharmacother 2018; 108: 11351140.

20.GANGI, S., FLETCHER, J.G., NATHAN, M.A. et al. Time interval between abnormalities seen on $\mathrm{CT}$ and the clinical diagnosis of pancreatic cancer: retrospective review of CT scans obtained before diagnosis. AJ R Am J Roentgenol 2004; 182: 897-903.

21. DAIANU O., GEORGESCU, A.M., CIUREA, M.E. et al. Temozolomide and targeted therapy against epidermal growth factor receptor in glioma. Int J Clin Exp Med 2016;9(8):15249-15261

22.AHMED, S., J OHNSON, P.T., HRUBAN, R., FISHMAN, E.K. Metastatic disease to the pancreas: pathologic spectrum and CT patterns. Abdom Imaging 2013; 38: 144-153.

23.SCHORTGEN, F., GIROU, E., DEYE, N., BROCHARD, L.; Cryco Study Group. Do hypooncotic fluids for shock increase the risk of lateonset acute respiratory distress syndrome? Intensive Care Med. 2010 Oct;36(10):1724-34.

24.BERCEANU, C., CIUREA, E.L., CIRSTOIU, M.M., BERCEANU, S., OFITERU, A.M., MEHEDINTU, C., BERBECE, S.I., CIORTEA, R., STEPAN, A.E., BALSEANU, A.T., Rev. Chim. (Bucharest), 69, no. 9, 2018, p. 2396-2401

25.BERBECE, S., ILIESCU, D., ARDELEANU, V., NICOLAU, A., JECAN, C.R. Rev. Chim. (Bucharest), 68, no. 7, 2017, p. 1438-1441

26.DEWITT, J., DEVEREAUX, B.M., LEHMAN, G.A. et al. Comparison of endoscopic ultrasound and computed tomography for the preoperative evaluation of pancreatic cancer: a systematic review. Clin Gastroenterol Hepatol 2006; 4: 717-725; quiz 664.

27.BERCEANU, C., PAITICI, S., BERCEANU, S., BRATILA, E., OFITERU, A.M., MEHEDINTU, C., BERBECE, S.I., NAVOLAN, D., OBLEAGA, C.V., BALSEANU, A.T., Rev. Chim. (Bucharest), 69, no. 8, 2018, p. 2245-2250 28.LU, D.S., REBER, H.A., KRASNY, R.M. etal. Local staging of pancreatic cancer: criteria for unresectability of major vessels as revealed by pancreatic-phase, thin-section helical CT. AJR Am J Roentgenol 1997; 168: 1439-1443.
29.FILIP, I.C., BERBECE, S., RADUCU, L., FLORESCU, I.P., ARDELEANU, V., JECAN, C.R., Mat. Plast., 54, no. 3, 2017, p. 414-417

30.BERBECE, S.I., CONDRATOVICI PLESEA, A., PAVEL, L.L., GRIGORE, A.C., Rev. Chim. (Bucharest), 68, no. 5, 2017, p. 1075-1076

31. ARDELEANU, V., BERBECE, S.I., FLORESCU, I.P., JECAN, C.R., Mat. Plast., 54, no. 1, 2017, p. 37-40

32.ITOH, S., YAMAKAWA, K., SHIMAMOTO, K. et al. CT findings in groove pancreatitis: correlation with histopathological findings. J Comput Assist Tomogr 1994; 18: 911-915.

33.RHA, S.E., JUNG, S.E., LEE, K.H. et al. CT and MR imaging findings of endocrine tumor of the pancreas according to WHO classification. Eur J Radiol 2007; 62: 371-377.

34.SANTO, E. Pancreatic cancer imaging: which method? JOP 2004; 5: 253-257.

35.J ECAN, C.R., NICOLAU, A., FLORESCU, I.P., ARDELEANU, V., BERBECE, S., Mat.Plast., 54, no. 1, 2017, p. 88-90

36.FUSARU, A.M., PISOSCHI, C.G., BOLD, A., TAISESCU, C.I. et al. Hypoxia induced VEGF synthesis in visceral adipose depots of obese diabetic patients. Rom J Morphol Embryol 2012, 53(4):903-909

37.*** Committee ASOP, GAN, S.I., RAJAN, E. et al. Role of EUS. Gastrointest Endosc 2007; 66: 425-434.

38.BRUGGE, W.R. The role of EUS in the diagnosis of cystic lesions of the pancreas. Gastrointest Endosc 2000; 52: S18-22.

39. PASCU, E.I., PISOSCHI, C.G., ANDREI, A.M., MUNTEANU, M.C. et al. Heterogeneity of collagen secreting cells in gingival fibrosis - an immunohistochemical assessment and a review of the literature. Rom J Morphol Embryol 2015, 56(1):49-61

40.PETRESCU, I.O., BICIUSCA, V., TAISESCU, C.I. et al. Histological factors that predict the liver fibrosis in patients with chronic hepatitis C. Rom J Morphol Embryol 2016, 57(2 Suppl):759-765.

41.NICHOLS, M.T., RUSS, P.D., CHEN, Y.K. Pancreatic imaging: current and emerging technologies. Pancreas. 2006 Oct;33(3):211-20.

42. ISHIGUCHI, T., OTA, T., NAGANAWA, S., FUKATSU, H., ITOH, S., ISHIGAKI, T. CT and MR imaging of pancreatic cancer. Hepatogastroenterology. 2001J ul-Aug;48(40):923-7.

Manuscript received: 14.12 .2018 